\title{
Interleukin-1 gene polymorphisms and periodontal status in a Spanish population
}

\author{
A. BASCONES-MARTÍNEZ ${ }^{1}$, G. VALDERRAMA ${ }^{1}$, F. VIJANDE ${ }^{1}$, A. PUYET-CATALINA ${ }^{2}$, \\ J. BASCONES-ILUNDAIN ${ }^{3}$, S. ARIAS-HERRERA ${ }^{1}$ and A. GARRIDO-PERTIERRA ${ }^{2}$ \\ ${ }^{1}$ Department of Medicine and Bucofacial Surgery, Dental School; \\ ${ }^{2}$ Department of Biochemistry and Molecular Biology, Faculty Veterinary; \\ ${ }^{3}$ Department of Conservative and Endodontic, Dental School, Complutense University, Madrid 28040, Spain
}

Received October 8, 2011; Accepted February 10, 2012

DOI: $10.3892 / \mathrm{mmr} .2012 .792$

\begin{abstract}
The aim of this study was to investigate the possible association between interleukin (IL)-1A (+4845) and/or IL-1B (+3954) gene polymorphisms and the onset and progression of chronic periodontal disease (PD), an issue that remains controversial. The relationship between IL-1 $\beta$ concentration in the gingival crevicular fluid (GCF) and disease activity was also evaluated. The study was performed on 25 individuals with no gingivitis or PD and on 25 subjects with active chronic PD. Two samples of GCF were obtained from each subject and IL-1 $\beta$ was determined by enzyme-linked immunoabsorbent assay. Blood samples $(10 \mathrm{ml})$ were drawn from each subject to detect polymorphisms in IL-1A (+4845) and IL-1B (+3954) by polymerase chain reaction. Mean GCF IL-1 $\beta$ concentrations were higher in patients with active chronic PD compared to the control group. No significant association was found in either group between GCF IL-1 $\beta$ concentration and the presence of polymorphisms in IL-1A (+4845), IL-1B (+3954) or both genotypes. No significant difference was found in either group with regard to the presence of polymorphisms in IL-1A (+4845), IL-1B (+3954) or both genotypes $(p=0.556)$. The concentration of IL-1 $\beta$ in GCF was almost 2-fold higher in patients with chronic PD than in the healthy individuals. The presence of polymorphisms in IL-1A (+4845) and/or IL-1B (+3954) genotypes is not associated with IL-1 $\beta$ overproduction in GCF and is not a risk factor for chronic PD. IL-1 $\beta$ is considered a suitable marker of the severity and progression of chronic PD. The presence of IL-1A (+4845) and/or IL-1B +3954 gene polymorphisms does not appear to be a risk factor for chronic PD. Therefore, the IL-1A (+4845) and/or IL-1B +3954 gene polymorphisms cannot be considered genetic markers of chronic PD. Moreover, these polymorphisms do not indicate an overproduction of IL-1 $\beta$ in GCF.
\end{abstract}

Correspondence to: Dr A. Bascones-Martínez, Departamento Medicina y Cirugía Bucofacial, Facultad de Odontología, Universidad Complutense de Madrid, Plaza Ramón y Cajal, s/n, 28040 Madrid, Spain

E-mail: antbasco@odon.ucm.es

Key words: interleukin-1, chronic periodontal disease, polymorphism

\section{Introduction}

Periodontal disease (PD) is a chronic inflammatory disease generated by a series of specific periodontopathogenic bacteria (1-4). Interleukin-1 (IL-1), together with other factors, is involved in the onset of tooth insertion tissue destruction $(5,6)$, and its synthesis is closely associated with PD severity and progression. Several studies have demonstrated that individuals exposed to the same environmental risk factors and with similar levels of dental care differ in their predisposition to PD $(7,8)$. Numerous cell families secrete IL-1, whose production is genetically determined by $I L-1 A, I L-1 B$ and $I L-I R N$ (9). Various polymorphisms in these genes have been associated with changes in the production of the corresponding proteins, IL-1 $\alpha$, IL-1 $\beta$ and IL-1ra $(10,11)$.

IL-1 $\beta$ inhibits bone formation by stimulating the synthesis of prostaglandins and tromboxans and the production of collagen and proteases $(12,13)$. In vitro studies have shown that IL-1 $\beta$ is 15 -fold more potent than IL- $1 \alpha$, and 500 -fold more potent than TNF- $\alpha$ in the inhibition of bone resorption (14). Moreover, 10 - to 50 -fold greater amounts of IL-1 $\beta$ than IL- $1 \alpha$ were isolated in periodontitis gingival crevicular fluid (GCF) from sites with PD (15).

An association between IL-1 polymorphisms and PD was reported by certain authors $(10,16,17)$. However, other authors found no such correlation (18-20), thus the issue remains controversial. The aim of the present study was to examine the association between IL-1 $\beta$ in GCF and PD activity and to investigate the presence of IL-1 gene polymorphisms and their possible relationship with the disease, in a Spanish population.

\section{Patients and methods}

Patients. This observational, cross-sectional case-control study was carried out on students of a Periodontics Master's course at our School of Dentistry. Two gender-matched groups of 25 patients each (12 males, 13 females) were randomly selected among the students with no gingivitis or periodontitis and those with moderate/severe PD, respectively. General inclusion criteria for the two groups were: subjects and their parents had to be of Spanish origin, subjects had to be non-smokers or ex-smokers for $>5$ years, subjects had to 
be free of any systemic disease (e.g., diabetes, HIV, immunological or haemorrhagic disorders), subjects were required not to have taken any antibiotics in the past 4 months, as well as be free of any chronic medication and not be pregnant or breastfeeding. Specific inclusion criteria for the healthy group were: absence of gingivitis, insertion loss $\leq 3 \mathrm{~mm}$ and absence of periodontal pockets.

Inclusion criteria for the PD group were: loss of insertion $\geq 5 \mathrm{~mm}$ in $\geq 2$ teeth in each quadrant, pocket depth $\geq 6 \mathrm{~mm}$ in $\geq 1$ tooth per quadrant, radiographic evidence of bone loss of $\geq 30 \%$, presence of $\geq 20$ teeth in the mouth (excluding third molars) with $\geq 1$ molar in each quadrant, and no periodontal treatment in the past year. The age range was 25-51 years in the PD group and 25-47 years in the healthy group.

Sample collection. Two samples were collected from the participants; from the mesiobuccal aspects of the two first upper molars in the healthy group, and from the deepest probing site showing disease activity, as defined by Lang et al (21), in each upper quadrant, in the PD group. To obtain the samples, the area was isolated with cotton rolls and air-dried with a syringe for $5 \mathrm{sec}$ at $45^{\circ}$ to the tooth root without desiccating the gingival groove. Subsequently, a paper strip (Harco Electronics, Irving, CA, USA) was introduced into the groove and left in place for $30 \mathrm{sec}$, avoiding contamination with blood or sputum. The strip was analyzed in a Periotron 8000 machine (Harco Electronics). Samples were stored at $-70^{\circ} \mathrm{C}$. IL-1 $\beta$ levels were measured using a streptavidin-peroxidase ELISA kit (Biosource Inc., Camarillo, CA, USA), according to the manufacturer's instructions. Immunodetection was performed by mixing $50 \mu \mathrm{l}$ of sample with $100 \mu \mathrm{l}$ of anti-IL-1 $\beta$ solution and quantifying the signal spectrophotometrically at a wavelength of $450 \mathrm{~nm}$.

Blood samples. A 10-ml sample of venous blood was obtained from all patients and submitted to standard analysis, verifying the absence of systemic diseases. An aliquot of this sample was used to isolate DNA as described by Miller et al (22).

Genetic polymorphism analysis. The presence of polymorphisms in the IL-1A and IL-1B genes was tested by the PCR amplification of DNA fragments encompassing the polymorphic site, followed by restriction and separation of the DNA fragments using electrophoresis on agarose gels (23). The specific conditions were as follows:

$I L-1 A(+4845)$. This polymorphism involves the substitution of $\mathrm{G}$ by $\mathrm{T}$ at the 4845 position, introducing a Fnu $4 \mathrm{H} 1$ recognition site. The primers used for amplification were: forward: 5'-ATG GTT TTA GAA ATC ATC AAG CCT AGG GCA and reverse: 5'-AAT GAA AGG AGG GGA GGA TGA CAG AAA TGT (23). The reaction was carried out in $50 \mu \mathrm{l}$ using Taq polymerase Gibco $^{\circledR} 5 \mathrm{IU}, 25 \mu \mathrm{M} \mathrm{MgCl}_{2}, 10 \mu \mathrm{M}$ dNTPs, $10 \mu \mathrm{M}$ of each primer and the reaction buffer (1X) supplied with the kit. Reactions were performed on a DNA thermal cycler (PCR system Perkin Etmer 2400) with the following thermal profile: 1 cycle of denaturation at $95^{\circ} \mathrm{C}$ for $10 \mathrm{~min}, 35$ cycles at $94^{\circ} \mathrm{C}$ for $30 \mathrm{sec}, 53^{\circ} \mathrm{C}$ for $30 \mathrm{sec}, 74^{\circ} \mathrm{C}$ for $30 \mathrm{sec}$ and an extension step at $72^{\circ} \mathrm{C}$ for $3 \mathrm{~min}$. The $153-\mathrm{bp}$ amplified DNA was digested with the restriction endonuclease $F n u 4 \mathrm{H} 1$, and the resulting products were visualized by elec-
Table I. Clinical characteristics of periodontal patients and controls.

\begin{tabular}{|c|c|c|}
\hline Mean & $\begin{array}{c}\text { Mean } \\
\text { standard } \\
\text { error }\end{array}$ & Median \\
\hline
\end{tabular}

\begin{tabular}{lrrrr}
\hline Case group $(\mathrm{n}=25)$ & & & & \\
IL-1 $\beta$ left $(\mathrm{pg} / \mu \mathrm{l})$ & 4.16 & 0.57 & 2.99 & 2.85 \\
IL-1 $\beta$ right $(\mathrm{pg} / \mu \mathrm{l})$ & 4.02 & 0.56 & 2.83 & 2.81 \\
Probing depth left & 6.20 & 0.16 & 6.00 & 0.82 \\
Probing depth right & 6.24 & 0.23 & 6.00 & 1.13 \\
Bleeding index & 74.69 & 3.00 & 74.80 & 15.02 \\
Plaque index & 77.07 & 3.78 & 78.10 & 18.92 \\
Age (years) & 41.96 & 1.66 & 43.00 & 8.31 \\
Control group & & & & \\
IL-1 $\beta$ left $(\mathrm{pg} / \mu \mathrm{l})$ & 2.30 & 0.29 & 1.84 & 1.46 \\
IL-1 $\beta$ right $(\mathrm{pg} / \mu \mathrm{l})$ & 2.38 & 0.28 & 1.93 & 1.42 \\
Probing depth left & 3.00 & 0.00 & 3.00 & 0.00 \\
Probing depth right & 3.00 & 0.00 & 3.00 & 0.00 \\
Bleeding index & 8.17 & 0.76 & 8.10 & 3.79 \\
Plaque index & 7.76 & 0.68 & 7.30 & 3.38 \\
Age (years) & 36.56 & 1.35 & 36.00 & 6.75 \\
\hline
\end{tabular}

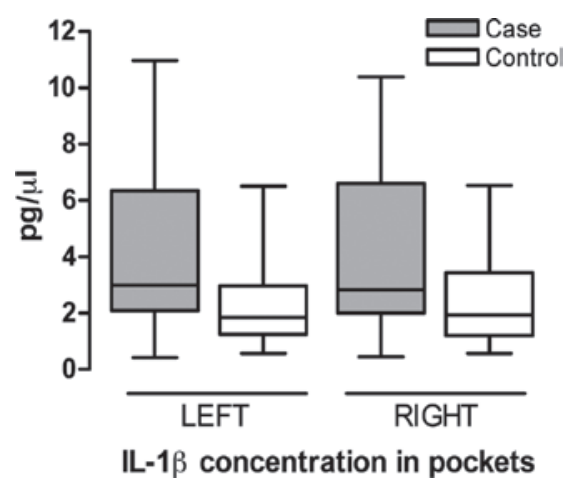

Figure 1. Distribution of IL-1 $\beta$ concentrations in the left and right pockets. Columns show the median value as a horizontal line. Error bars show the upper and lower limits of the $95 \%$ confidence interval.

trophoresis on 1.5 and $3 \%$ agarose gels stained with ethidium bromide. The polymorphism was detected by the appearance of two fragments of 124 and $29 \mathrm{bp}$.

$I L-1 B(+3954)$. This polymorphism is characterized by the substitution of $\mathrm{C}$ by $\mathrm{T}$ at the +3953 position, leading to the appearance of a $T a q 1$ site. The primers used were: forward: 5'-CTC AGG TGT CCT CGA AGA AAT CAA and reverse: 5'-GCT TTT TTG CTG TGA GTC CCG, producing an amplicon of $182 \mathrm{bp}$. The amplified reaction mixture $(50 \mu \mathrm{l})$ contained 10X PCR buffer, $25 \mu \mathrm{M} \mathrm{MgCl}_{2}, 10 \mu \mathrm{M}$ dNTPs, $10 \mu \mathrm{M}$ of each primer and $5 \mathrm{IU}$ of PCR Taq polymerase (Gibco). The reactions were performed as above, but using $50^{\circ} \mathrm{C}$ as the annealing temperature. The amplified DNA was digested with restriction endonuclease Taq 1 and the resulting products were visualized on agarose gels, as above. Expected fragment sizes in homozygotes carrying the polymorphism were 97 and $85 \mathrm{bp}$. 
Table II. Concentrations of GCF IL-1 $\beta$ in the left and right pockets in the PD and control groups.

\begin{tabular}{lccc}
\hline Group & No. & $\begin{array}{c}\text { Mean } \\
(\mathrm{pg} / \mu \mathrm{l})\end{array}$ & $\begin{array}{c}\text { Bilateral } \\
\text { asymptotic } \\
\text { significance (p) }\end{array}$ \\
\hline IL-1 $\beta$ left & & & \\
PD & 25 & 30.48 & 0.016 \\
Control & 25 & 20.52 & \\
IL-1 $\beta$ right & & & 0.039 \\
PD & 25 & 29.76 & \\
Control & 25 & 21.24 & \\
\hline
\end{tabular}

Table III. Distribution of IL-1A (+4845) and IL-1B (+3954) polymorphisms in the study population.

\begin{tabular}{lcc}
\hline & IL-1A [no. (\%)] & IL-1B $\quad[$ no \\
\hline 1.1 & & \\
1.2 & $27(54)$ & $28(56)$ \\
2.2 & $18(36)$ & $20(40)$ \\
Total & $5(10)$ & $2(4)$ \\
\hline
\end{tabular}

1.1 , non-polymorphic homozygote; 1.2 , heterozygote; 2.2 , polymorphic homozygote.

Table IV. Prevalence of polymorphisms in the two genes in the study population.

\begin{tabular}{lcr}
\hline Genotype & No. & $\%$ \\
\hline Negative & 32 & 64 \\
Positive & 18 & 36 \\
Total & 50 & 100 \\
\hline
\end{tabular}

Positive, at least one polymorphic allele at IL-1A and one polymorphic allele at IL-1B; negative, at least one non-polymorphic gene.

Statistical analysis. Since the Kolmogorov-Smirnov test showed an abnormal distribution, the data were analyzed with non-parametric tests: the Spearman Rho correlation, KruskalWallis, Mann-Whitney U and Chi-square tests. $\mathrm{P}<0.05$ was considered statistically significant. SPSS 12.0 (SPSS Inc., Chicago, IL, USA) was used for the data analyses.

\section{Results}

Table I summarises the clinical characteristics of the PD and the control group. Mean probing depths, bleeding and plaque indices were consistently higher in the PD than in the control group. GCF IL-1 $\beta$ concentrations were almost 2-fold higher in the PD group than in the control group (left pocket:
Table V. Distribution of IL-1A (+4845) and IL-1B (+3954) polymorphisms between patients with $\mathrm{PD}$ and healthy controls.

\begin{tabular}{|c|c|c|c|c|c|c|c|c|}
\hline & \multicolumn{3}{|c|}{ IL-1A } & \multicolumn{3}{|c|}{ IL-1B } & \multicolumn{2}{|c|}{ Genotype } \\
\hline & 1.1 & 1.2 & 2.2 & 1.1 & 1.2 & 2.2 & No & Yes \\
\hline PD (\%) & 64 & 28 & 8 & 64 & 32 & 4 & 68 & 32 \\
\hline Control (\%) & 44 & 44 & 12 & 48 & 48 & 4 & 60 & 40 \\
\hline
\end{tabular}

Table VI. Mean range of IL- $1 \beta$ concentrations $(\mathrm{pg} / \mu \mathrm{l})$ in the GCF of subjects with IL-1A (+4845) and/or IL-1B (+3954) alleles.

\begin{tabular}{lccc}
\hline & Heterozygosis & IL-1A & IL-1B \\
\hline IL-1 $\beta$ left & 1.1 & 25.74 & 25.89 \\
& 1.2 & 24.61 & 25.20 \\
& 2.2 & 27.40 & 23.00 \\
IL-1 $\beta$ right & & & \\
& 1.1 & 25.96 & 25.89 \\
& 1.2 & 24.56 & 25.00 \\
& 2.2 & 26.40 & 25.00 \\
\hline
\end{tabular}

IL-1A (+4845): left pocket, $\chi^{2}=0.159, \mathrm{p}=0.923$; right pocket, $\chi^{2}=0.122, \mathrm{p}=0.941$; IL-1B $(+3953)$ : left pocket, $\chi^{2}=0.088, \mathrm{p}=0.957$; right pocket, $\chi^{2}=0.046, \mathrm{p}=0.977$.

Table VII. Mean range of IL- $1 \beta$ concentrations $(\mathrm{pg} / \mu \mathrm{l})$ in the GCF of subjects with positive or negative genotypes.

\begin{tabular}{lcc}
\hline & Genotype & Mean \\
\hline IL-1 $\beta$ left & Positive & 25.53 \\
& Negative & 25.44 \\
IL-1 $\beta$ right & Positive & 25.91 \\
& Negative & 24.78 \\
\hline
\end{tabular}

Left, Mann-Whitney U test $=287.000, \mathrm{p}=0.984$; right, Mann-Whitney $\mathrm{U}$ test $=275.000, \mathrm{p}=0.793$.

$4.161 \pm 2.854$ vs. $2.3 \pm 1.5 \mathrm{pg} / \mu 1, \mathrm{p}=0.039$; right pocket: $4.0 \pm 2.8$ vs. $2.4 \pm 1.4 \mathrm{pg} / \mu \mathrm{l}, \mathrm{p}=0.016$ ) (Fig. 1 , Table II).

In the global samples (cases and controls), $46 \%$ were shown to be IL-1A (+4845) gene polymorphisms, 44\% IL-1B (+3954) polymorphisms and $36 \%$ both polymorphisms (Tables III and IV). As shown in Table V, the groups did not significantly differ in the prevalence of IL-1A (+4845) or IL-1B $(+3954)$ polymorphisms $(\mathrm{p}=0.504)$ or both (positive genotype).

No significant correlations were found between GCF IL-1 $\beta$ concentrations and probing depth, insertion loss, plaque index or bleeding index, between GCF IL-1 $\beta$ concentrations 
and the IL-1A (+4845) polymorphism, between GCF IL-1 $\beta$ and the IL-1B (+3954) polymorphism, or between GCF IL-1 $\beta$ concentrations and polymorphisms in the two genes (Tables VI and VII).

\section{Discussion}

Relationship between GCF IL-1 $\beta$ and periodontal status. In this study, IL-1 $\beta$ was detected in the GCF of the studied sites of the subjects, as has also been reported by Preiss and Meyle (24), and Rawlison et al (25). By contrast, Suwatanapongched et al (26) and Wilton et al (27) failed to detect IL-1 $\beta$ in GCF at healthy sites. This discrepancy may result from the use of different sampling methods and/or ELISA kits. GCF IL-1 $\beta$ concentrations were almost 2 -fold higher $(\mathrm{p}<0.05)$ in our PD patients than in the healthy controls, consistent with reports of a strong relationship between IL-1 $\beta$ and periodontal inflammation (26,28-31). Masada et al (32), in a study of 15 patients with moderate-to-severe PD, found that their elevated GCF IL- $1 \alpha$ and IL-1 $\beta$ concentrations were reduced with periodontal treatment. Salvi et al (33) reported higher GCF IL-1 $\beta$ concentrations in patients with moderateto-severe periodontitis than in patients with gingivitis and moderate periodontitis.

Giannopoulou et al (34) also observed higher concentrations of GCF IL-1 $\beta$ in PD patients than in gingivitis patients and healthy controls, and reported higher levels in active vs. non-active sites among the PD patients; healthy sites showed higher levels of IL-4, which is considered to have a protective effect against PD, whereas IL- $1 \beta$, IL- 6 and IL- 8 were associated with periodontal destruction.

Relationship between IL-1 polymorphisms and periodontal status. No significant difference was found between the groups with regard to the presence of IL-1 gene polymorphisms. This result is in line with the report by Rogers et al (18) whose findings indicated no difference among groups with chronic PD, early-onset periodontitis, and no PD in the presence of IL-1A (+4845) polymorphism or positive genotype. These authors did not detect any correlation between IL-1 polymorphisms and susceptibility to implant loss. Results of a study by Papapanou et al (19) found no differences in the prevalence of positive or negative genotypes between PD patients and healthy individuals. By contrast, Galbraith et al (16) and Gore et al (10) observed a correlation between the IL-1B (+3953) polymorphism and the presence of advanced PD when smokers were included in the study group, although the relationship did not reach statistical significance, stating that individuals with this polymorphism are 3 -fold more susceptible to PD. Kornman et al (17) found a significantly higher prevalence of positive genotypes in non-smokers with severe PD, and Shirodaria et al (35) reported a significant association between the IL-1A polymorphism (+4845) and a higher risk of severe PD in non-smokers. However, findings of studies from 3 consecutive years $(20,36,37)$ showed that only smokers with positive IL-1 genotype were at a higher risk of PD, concluding that tobacco use is a more important risk factor than genetics. Drozdzik et al (38) found no significant association between the presence of the IL-1B polymorphism $(+3953)$ and the periodontal status of patients, consistent with the present study, describing plaque index and age as more influential risk factors. By contrast, Agrawal et al (39) reported that the presence of IL-1 gene polymorphisms is a clear risk factor for chronic PD, finding significant differences between healthy non-smokers and non-smoking patients with severe chronic PD. A recent review by Huynh-Ba et al (40) reflected the discrepancies among published clinical findings and concluded that the evidence on the contribution of IL-1 gene polymorphisms on PD progression was inadequate. These authors also suggested that the results of certain commercial genetic tests should be interpreted with caution.

Correlation between the GCF IL-1 $\beta$ concentration and the presence of polymorphisms. No significant correlation between GCF IL-1 $\beta$ and any polymorphism studied was found. This observation is consistent with previous reports whereby positive or negative IL-1 genotypes have no effect on IL-1 $\beta$ production in monocytes exposed to periodontal pathogens (41). However, reports on this relationship have been controversial, with findings of a decrease (42) and an increase (10) in IL-1 $\beta$ production by peripheral mononuclear cells in individuals with the IL-1 $\beta(+3953)$ polymorphism. Pociot et al (11) found that, following exposure to Escherichia coli lipopolysaccharides, $30-40 \%$ more IL-1 $\beta$ was produced in IL-1B (+3953) heterozygotes and 50\% more in IL-1B (+3953) homozygotes compared to those with a negative genotype, regardless of their periodontal status.

In conclusion, GCF IL- $1 \beta$ concentrations are higher in individuals with active chronic PD than in healthy individuals. GCF IL-1 $\beta$ concentrations do not differ among PD-affected pockets in the same individual. IL- $1 \beta$ is considered a suitable marker of the severity and progression of chronic PD. The presence of IL-1A (+4845) and/or IL-1B +3954 gene polymorphisms does not appear to be a risk factor for chronic PD. Moreover, IL-1A (+4845) and/or IL-1B +3954 gene polymorphisms cannot be considered genetic markers of this condition and they do not indicate an overproduction of IL- $1 \beta$ in GCF. Nevertheless, further study on genetic variations in different populations is required to elucidate the role of genetic factors in the onset and progression of periodontal disease.

\section{References}

1. Costerton JW, Stewart PS and Greenberg EP: Bacterial biofilms: a common cause of persistent infections. Science 21: 1318-1322, 1999.

2. Löe H, Theilade E and Jensen SB: Experimental gingivitis in man. J Periodontol 36: 177-187, 1965.

3. Theilade E, Wright WH, Jensen SB and Löe H: Experimental gingivitis in man. II. A longitudinal clinical and bacteriological investigation. J Periodontal Res 1: 1-13, 1966.

4. Löe H, Theilade E, Jensen SB and Schiott CR: Experimental gingivitis in man. III. Influence of antibiotics on gingival plaque development. J Periodontal Res 2: 282-289, 1967.

5. Gowen M, Wood DD, Ihrie EJ, Mcguire MK and Russell RG: An interleukin-1 like factor stimulates bone resorption in vitro. Nature 306: 378-380, 1983.

6. Tatakis DN, Schneeberger G and Dziak R: Recombinant interleukin-1 stimulates prostaglandin E2 production by osteoblastic cells: synergy with parathyroid hormone. Calcif Tissue Int 42: 358-362, 1988.

7. Löe H, Anerud A, Boysen H and Morrison E: Natural history of periodontal disease in man. Rapid, moderate and no loss of attachment of Sri Lankan laborers 14 to 46 of age. J Clin Periodontol 13: 431-445, 1986. 
8. Michalowicz BS: Genetic and heritable risk factors in periodontal disease. J Periodontol 65: 479-488, 1994.

9. Nicklin MJ, Weith A and Duff GW: A physical map of the region encompassing the human interleukin-1 alpha, interleukin-1 beta, and interleukin-1 receptor antagonist genes. Genomics 19: 382-384, 1994.

10. Gore EA, Sanders JJ, Pandey JP, Palesch Y and Galbraith GM: Interleukin- $1 \beta+3953$ allele 2 : association with disease status in adult periodontitis. J Clin Periodontol 25: 781-785, 1998.

11. Pociot F, Molvig J, Wogensen L, Worsaae H and Nerup J: A Taq1 polymorphism in the human interleukin-1 beta (IL-1beta) gene correlates with IL-1 beta secretion in vitro. Eur J Clin Invest 22 396-402, 1992

12. Slots J: Actinobacillus actinomycetemcomitans and porphyromona gingivalis in periodontal disease: introduction. Periodontol 2000 20: 7-13, 1999.

13. Albandar JM, Olsen I and Gjermo P: Associations between six DNA probe-detected periodontal bacteria and alveolar bone loss and other clinical signs of periodontitis. Acta Odontol Scand 48: 415-423, 1990.

14. Tatakis DN: Interleukin-1 and bone metabolism: a review. J Periodontol 64: 416-431, 1993.

15. Stashenko P, Dewhirst FE, Peros WJ, Kent RL and Ago JM: Synergistic interactions between interleukin-1, tumor necrosis factor, and lymphotoxin in bone resorption. J Immunol 138 1464-1468, 1987 .

16. Galbraith GM, Hagan C, Steed RB, Sanders JJ and Javed T: Cytokine production by oral and peripheral blood neutrophils in adult periodontitis. J Periodontol 68: 832-838, 1997.

17. Kornman KS, Crane A, Wang HY, et al: The interleukin-1 genotype as a severity factor in adult periodontal disease. J Clin Periodontol 24: 72-77, 1997.

18. Rogers MA, Figliomeni L, Baluchova K, et al: Do interleukin-1 polymorphisms predict the development of periodontitis or the success of dental implants? J Periodontal Res 37: 37-41, 2002.

19. Papapanou PN, Neiderud AM, Sandros J and Dahlén G: Interleukin-1 gene polymorphism and periodontal status. A casecontrol study. J Clin Periodontol 28: 389-396, 2001.

20. Meisel P, Schwahn C, Gesch D, Bernhardt O, John U and Kocher T: Dose-effect relation of smoking and the interleukin-1 gene polymorphism in periodontal disease. J Periodontol 75 : 236-242, 2004

21. Lang NP, Joss A, Orsanic T, Gusberti FA and Siegrist BE: Bleeding on probing. A predictor for the progression of periodontal disease. J Clin Periodontol 13: 590-596, 1986

22. Miller SA, Dykes DD and Polesky HF: A simple salting out procedure for extracting DNA from human nucleated cells Nucleic Acids Res 16: 1215, 1988

23. Walker SJ, Van Dyke TE, Rich S, Kornman KS, di Giovine FS and Hart TC: Genetic polymorphisms of the IL-1alpha and IL-1beta genes in African-American LJP patients and an African-American control population. J Periodontol 71: 723-728, 2000

24. Preiss DS and Meyle J: Interleukin-1 beta concentration of gingival crevicular fluid. J Periodontol 65: 423-428, 1994.

25. Rawlinson A, Dalati MH, Rahman S, Walsh TF and Fairclough AL: Interleukin-1 and IL-1 receptor antagonist in gingival crevicular fluid. J Clin Periodontol 27: 738-743, 2000.

26. Suwatanapongched P, Laohapand P, Surarit R, Ohmoto Y and Ruxrungtham K: Interleukin- $1 \beta$ level in gingival crevicular fluid of patients with active periodontitis. Asian Pac J Allergy Immunol 18: 201-207, 2000.
27. Wilton JMA, Bampton JLM and Griffiyhs GS: Interleukin-1 beta (IL-1 $\beta$ ) levels in gingival crevicular fluid: implications for the pathogenesis of periodontal disease. J Clin Periodontol 19: 53-57, 1992.

28. Lee HJ, Kang IK, Chung CP and Choi SM: The subgingival microflora and gingival crevicular fluid cytokines in refractory periodontitis. J Clin Periodontol 22: 885-890, 1995.

29. Ishihara Y, Nishihara T, Koroyanagi T, et al: Gingival crevicular interleukin-1 and interleukin-1 receptor antagonist levels in periodontally healthy and diseased sites. J Periodontal Res 32: 524-529, 1997.

30. Gamonal J, Jorge $\mathrm{O}$ and Silva A: Interleuquina-1 $\beta$ e interleuquina-8 en pacientes adultos con periodontitis destructiva: efectos del tratamiento periodontal. Av Periodon Implantol 11: 183-193, 1999.

31. Figueredo CM, Ribeiro MS, Fischer RG and Gustafsson A Increased interleukin-1 beta concentration in gingival crevicular fluid as a characteristic of periodontitis. J Periodontol 70: 1457$1463,1999$.

32. Masada MP, Persson R, Kenney JS, Lee SW, Page RC and Allison AC: Measurement of interleukin-1 alpha and -1 beta in gingival crevicular fluid: implications for the pathogenesis of periodontal disease. J Periodontal Res 25: 156-163, 1990.

33. Salvi GE, Yalda B, Collins JG, et al: Inflammatory mediator response as a potential risk marker for periodontal diseases in insulin-dependent diabetes mellitus patients. J Periodontol 68 127-135, 1997.

34. Giannopoulou C, Kamma JJ and Mombelli A: Effect of inflammation, smoking and stress on gingival crevicular fluid cytokine level. J Clin Periodontol 30: 145-153, 2003.

35. Shirodaria S, Smith J, Mckay IJ, Kennett CN and Hughes FJ: Polymorphisms in the IL- $1 \alpha$ gene are correlated with levels of interleukin-1 alpha protein in gingival crevicular fluid of teeth with severe periodontal disease. J Dent Res 79: 1864-1869, 2000.

36. Meisel P, Siegemund A, Dombrowa S, Sawaf H, Fanghaenel J and Kocher T: Smoking and polymorphisms of the interleukin-1 gene cluster (IL-1 $\alpha$, IL-1 $\beta$ and IL-RN) in patients with periodontal disease. J Periodontol 73: 27-32, 2002.

37. Meisel P, Siegemund A, Grimm R, et al: The interleukin-1 polymorphism, smoking, and the risk of periodontal disease in the population-based SHIP study. J Dent Res 82: 189-193, 2003.

38. Drozdzik A, Kurzawski M, Safronow K and Banach J: Polymorphism in interleukin- $1 \beta$ gene and risk of periodontitis in a Polish population. Adv Med Sci 51 (Suppl 1): 13-17, 2006.

39. Agrawal AA, Kapley A, Yeltiwar RK and Purohit HJ Assessment of single nucleotide polymorphism at IL-1 A+4845 and IL-1B+3954 as genetic susceptibility test for chronic periodontitis in Maharashtrian ethnicity. J Periodontol 77: 1515-1521, 2006.

40. Huynh-Ba G, Lang NP, Tonetti MS and Salvi GE: The association of the composite IL-1 genotype with periodontitis progression and/or treatment outcomes: a systematic review. J Clin Periodontol 34: 305-317, 2007.

41. Mark LL, Haffajee AD, Socransky SS, et al: Effect of the interleukin-1 genotype on monocyte IL-1beta expression in subjects with adult periodontitis. J Periodontal Res 35: 172-177, 2000

42. Santtila S, Savinainen K and Hurme M: Presence of the IL-1RA allele 2 (ILI-1RN*2) is associated with enhanced IL-1 $\beta$ production in vitro. Scand J Immunol 47: 195-198, 1998. 